\title{
Fatal parasitosis in blackbucks (Antilope cervicapra): a possible factor risk in hunting units
}

\section{Parasitosis fatal en el antílope negro (Antilope cervicapra): un posible factor de riesgo en unidades de cacería}

\author{
Ned de la Cruz-Hernández, ${ }^{1}$ M.Sc, Edgar López-Acevedo, ${ }^{1}$ M.Sc, \\ Lorena Torres-Rodríguez, ${ }^{1}$ M.Sc, Gabriel Aguirre-Guzmán, ${ }^{1 *}$ Ph.D.
}

${ }^{1}$ Universidad Autónoma de Tamaulipas, Facultad de Medicina Veterinaria y Zootecnia, Km 5 Carretera
Victoria-Mante, Ciudad Victoria, Tamaulipas, México. *Correspondence: gabaguirre@uat.edu.mx

Received: April 2014; Acepted: February 2015.

\begin{abstract}
In February 2012, a reproductive group of 60 adult blackbucks (Antilope cervicapra) from Veracruz, Mexico was relocated to hunting units in eastern and northeastern Mexico. Seven individuals died due to hemorrhagic parasitic, abomasitis and enteritis caused by Haemonchus spp., Setaria spp., and Trichostrongylids. Deaths were associated with hepatic necrosis, bilateral congestive distention of heart and fibrinonecrotic bronchopneumonia. Also Anaplasma marginale was identified. The blackbucks' population displayed a general mortality rate of $11.67 \%$, where $25 \%$ of total male and $9.62 \%$ of total female died. The mortality was controlled by segregation of all remaining blackbucks and the treatment for internal and external parasites (biting flies and ticks). After the treatment, no fatality cases related to parasitosis were recorded. The results presented here exhibit the high relevance of parasitosis as possible factor risk in the survival of tis specie.
\end{abstract}

Key words: Anaplasma marginale, antelope, diseases, hunting, parasite, trichostrongylids (Source:CAB).

\section{RESUMEN}

En febrero del 2012, un grupo de 60 individuos adultos reproductivos de antílope negro (Antilope cervicapra) provenientes de Veracruz, México fueron reubicado en unidades de cacería del este y noreste de este país. Siete individuos murieron presentando hemorragias parasíticas, abomasitis y enteritis ocasionadas por Haemonchus spp., Setaria spp. y Trichostrongylids. Las muertes estuvieron asociadas con necrosis hepática, distensión congestiva del corazón y bronconeumonía fibronecrótica, donde Anaplasma marginale fue identificada. La población de antílopes negros mostró un porcentaje de mortalidad del $11.67 \%$, en donde el 25 y $9.62 \%$ de los machos y hembras totales murieron. La mortalidad fue controlada mediante el aislamiento de los antílopes negros restantes y un tratamiento contra parásitos internos y externos (garrapatas y moscas picadoras), lo cual controló las mortalidades y reveló la importancia de la parasitosis como factor de riesgo que afecta la sobrevivencia de esta especie.

Palabras claves: Anaplasma marginale, antílope, caza, enfermedad, parásitos, trichostrongylids, (Fuente:CAB). 


\section{INTRODUCTION}

The blackbucks (Antilope cervicapra) are indigenous to the Indian subcontinent where their population has decreased for excessive hunting and loss of their natural habitat $(1,2)$. The population of this specie is expected to decline in the next decade and a become vulnerable or threatened.

In Mexico (Figure 1) as in other countries, blackbuck has been introduced in hunting units, where they have increased their populations rapidly and have produced important economic resources as an exotic hunt product $(1,3)$. Low information about the parasites diseases of exotic blackbucks in hunting units has been little studied (4). Some parasites as Amphistoma sp., Camelostrongylus mentulatus, Haemonchus contortus, Neospora caninum, Nematodirus spathiger, Oesophagostomum sp Strongyle sp., Strongyloides sp., Trichostrongylus axei, $T$. colubriformis, T. probolurus, Toxoplasma gondii and Trichuris have been identified and associated with disease and mortality of $A$. cervicapra (4-6). In Mexico, only one survey has been carried out involving a hunting unit with free-ranging blackbuck populations (7). Thus, the objective of this study was to describe a fatal parasitic disease associated with respiratory lesions in a hunting unit with free-ranging blackbucks re-located in northeastern, Mexico.

\section{CASE HISTORY}

Clinical findings. In February 2012, a group of 60 adult blackbucks ( 8 males and 52 females, $37-42 \mathrm{~kg}$ ) was translocated for reproduction from the State of Veracruz, Mexico to a hunting unit with free-ranging animals in Padilla, Tamaulipas, Mexico (Figure 1 ). This area is located in the coordinates $24^{\circ} 03^{\prime} \mathrm{N}$ and $98^{\circ} 37^{\prime} \mathrm{W}$ and show $153 \mathrm{MASL}$, an average annual rainfall of $700 \mathrm{~mm}$ and an average annual of $22^{\circ} \mathrm{C}$ (ranging from 1 to $43^{\circ} \mathrm{C}$ ).

Two weeks post-introduction to the grassland, seven blackbucks (two males and five females) presented an acute clinical history related with abdominal pain, feces with abundant mucus, hair loss, pale membranes (anemia), progressive wasting, prostration, seborrhea, skin lesions due to fly-bites, and weakness; however, the animals did not present fever. These clinical signs lasted for one week before the death of the blackbucks.

Pathological analysis. Dead animals were transported to the Pathology Laboratory of Facultad de Medicina Veterinaria y Zootecnia of

\section{INTRODUCCION}

Los antílopes negros (Antilope cervicapra) son nativos del subcontinente Indio, en donde su población ha disminuido por exceso de caza y pérdida de su hábitat natural $(1,2)$. En la próxima década, se espera que haya un descenso de la población hasta que esta especie se convierta en vulnerable y amenazada.

En México (Figura 1) como en otros países, el antílope se ha introducido en unidades de cacería, en donde su población aumenta rápidamente y produce grandes recursos económicos como un producto de cacería exótica $(1,3)$. Existe poca información sobre los estudios acerca de las enfermedades parasitarias de los antílopes exóticos en las unidades de cacería (4). Se han identificado algunos parásitos como Amphistoma sp., Camelostrongylus mentulatus, Haemonchus contortus, Neospora caninum, Nematodirus spathiger, Oesophagostomum sp., Strongyle sp., Strongyloides sp., Trichostrongylus axei, T. colubriformis, T. probolurus, Toxoplasma gondii y Trichuris y se han relacionado con la enfermedad y la mortalidad de $A$. cervicapra (4-6). En México, se ha llevado a cabo solamente una investigación que involucra una unidad de cacería con poblaciones de antílopes negros criados en libertad (7). Así, el objetivo de este estudio fue describir una enfermedad parasitaria fatal relacionada con lesiones respiratorias en una unidad de cacería con antílopes re ubicados y criados en libertar en el noreste de México.

\section{HISTORIA DEL CASO}

Resultados clínicos. En febrero del 2012, se trasladó un grupo de 60 antílopes negros (8 machos y 52 hembras, $37-42 \mathrm{~kg}$ ) para su reproducción desde el estado de Veracruz, México hasta la unidad de cacería con animales criados en libertad, en Padilla, Tamaulipas, México (Figura 1). Esta área está localizada en las coordenadas $24^{\circ} 03^{\prime} \mathrm{N}$ y $98^{\circ} 37^{\prime} \mathrm{O}$ y a $153 \mathrm{msnm}$ (metros sobre el nivel del mar), con un promedio anual de precipitaciones de $700 \mathrm{~mm}$ y una temperatura promedio anual de $22^{\circ} \mathrm{C}$ (rango de 1 a $43^{\circ} \mathrm{C}$ ).

Dos semanas después de la introducción al pastizal, siete antílopes negros (dos machos y cinco hembras) presentaron una historia clínica aguda relacionada con dolor abdominal, heces con moco abundante, pérdida de pelo, membranas pálidas (anemia), atrofia progresiva, postración, seborrea, lesiones de la piel debidas a picaduras de mosca, y debilidad; sin embargo, los animales no presentaron fiebre. Estos síntomas clínicos continuaron por una semana, antes de la muerte de los antílopes. 


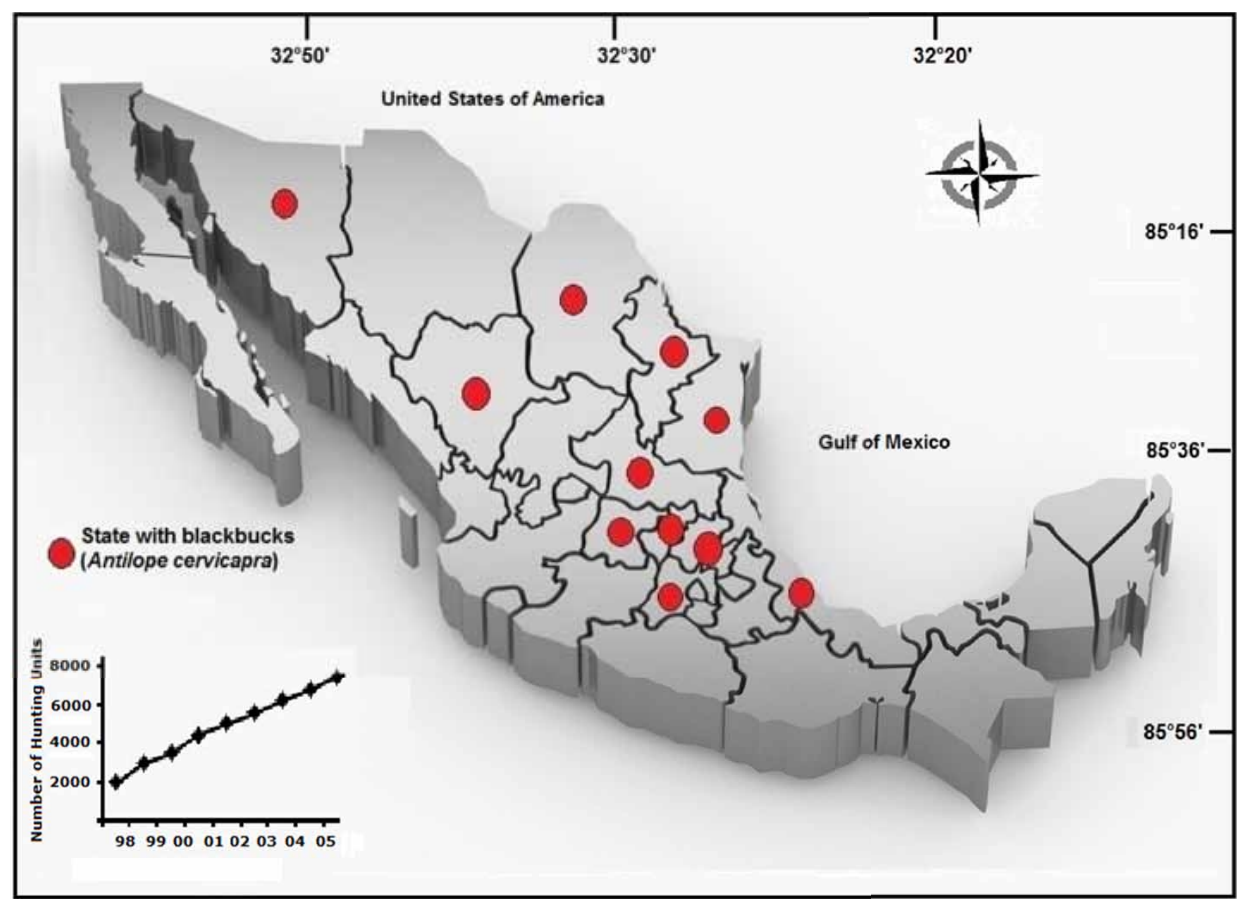

Figure 1. Growth of hunting units in Mexico from 1998 to 2013 and States of Mexico (Coahuila, Durango, Estado de México, Guanajuato, Hidalgo, Nuevo León, Puebla, Querétaro, San Luis Potosi, Sonora, Tamaulipas and Veracruz) with hunting units of blackbucks (Antilope cervicapra) (2).

the Universidad Autonoma de Tamaulipas for diagnosis as part of the continuing cooperation with productive hunting unit and wildlife agency' in Mexico (Figure 2a). Pathology evaluation was carried out in the seven blackbucks where main identified gross signs and histopathological lesions from different tissues (brain, hearth, liver, kidney, and tissues form digestive, respiratory and reproductive system) were analyzed according to standard protocol. Samples should be fixed in buffered formalin $10 \%$, processed routinely, embedded in paraffin, sectioned and stained with hematoxylin-eosin stain. In addition, blood samples were collected from the sacrificed animals (lung and heart) and placed immediately on ice. EDTA was used as an anticoagulant and non-coagulated blood was tested, shortly after collection, for packed cells volume, and hemoglobin by microhematocit and spectrophotometry respectively. Also, blood samples were stained with Giemsa. Blood samples were fixed ( $1 \mathrm{~min}$ ) in absolute methanol and stained with $10 \%$ Giemsa for $30 \mathrm{~min}$. After staining, samples were washed three or four times with tap water to remove adhering stain and then air dried. The samples are examined under oil immersion to increased 700-1000 x.
Análisis patológico. Los animales muertos se transportaron al Laboratorio de Patología de la Facultad de Medicina, Veterinaria y Zootecnia de la Universidad Autónoma de Tamaulipas para su diagnóstico, como parte de la cooperación continuada con la unidad de cacería productiva y la oficina de vida silvestre en México (Figura 2a). Se llevó a cabo una evaluación patológica de los siete antílopes negros, identificando los principales síntomas masivos y analizando las lesiones histopatológicas de diferentes tejidos (cerebro, corazón, hígado, riñón, y los que forman los sistemas digestivo, respiratorio y reproductivo) de acuerdo con el protocolo estándar. Las muestras se fijaron con formalina tampón al $10 \%$, se procesaron rutinariamente, se mezclaron con parafina, se separaron y se tiñeron con tinte hematoxylinaeosina. Además, se recolectaron muestras de sangre de los animales sacrificados (pulmón y corazón) y se colocaron inmediatamente en hielo. Se usó como anticoagulante EDTA y rápidamente se analizó la sangre no coagulada para medir el volumen de células empacadas o hematocritos y hemoglobina mediante microhematocitos y espectrofotometría, respectivamente. Además, las muestras de sangre se tiñeron con Giemsa al $10 \%$ por 30 minutos, después de fijarse $(1 \mathrm{~min})$ con metanol absoluto. Después de la tinción, las muestras se lavaron tres o cuatro veces con agua corriente para remover la tintura adherida, luego 


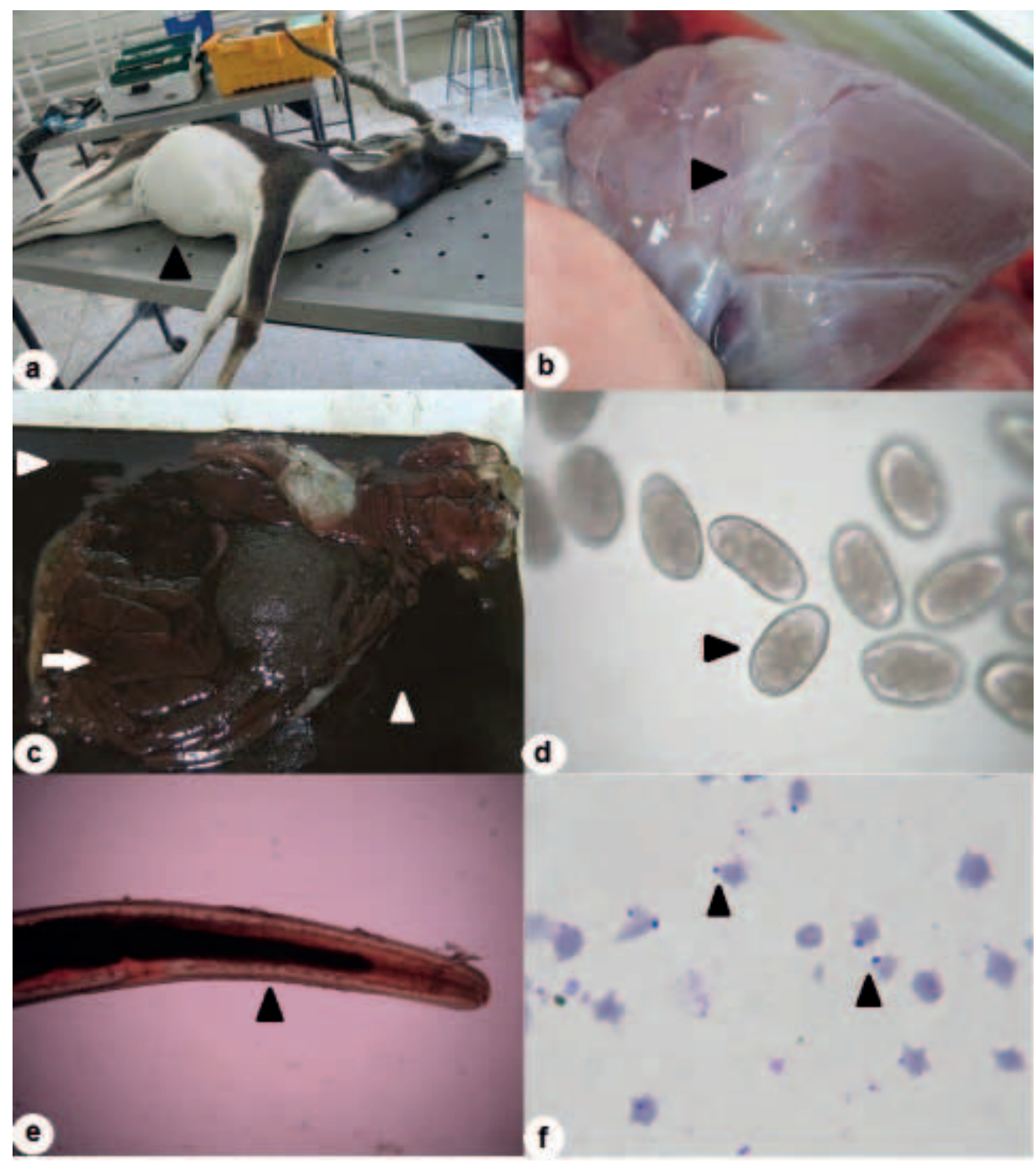

Figure 2. a) Male of Antilope cervicapra with abdominal distension (head arrow), b) Brown atrophy with gelatinous degradation of adipose tissue in coronary artery (head arrow), c) Severe injury to abomasum and edema in mucosal tissue (white arrow), abomasal fluid with high level of blood (white head arrow), d) High number of Trichostrongylus spp eggs (head arrow), e) Light micrographs showing a fresh specimen of Setaria spp. from gut and abdominal cavity (head arrow) (4X), and f) Anaplasma marginale (head arrow) as basophilic and spherical inclusions located near the margin of erythrocytes (100X, Giemsa stained).

\section{CLINICAL RESULTS}

The diseases impact in introduced wildlife species on local wildlife populations has become a recent issue of global priority, which is critical when disease risks involve the livestock industries and human health $(1,8-10)$. The blackbucks (A. cervicapra) were introduced to Mexico for their importance as trophy hunting. The study population in the hunting unit consisted of 60 adult blackbucks ( 8 studs male and 52 reproductive females). The general mortality rate was $11.67 \%$, but the sex-specific mortality rates were $25 \%(n=2)$ and $9.62 \%(n=5)$ for male and female, respectively. se secaron con aire y se examinaron con aceite de inmersión para aumentos de 700-1000 x.

\section{RESULTADOS CLINICOS}

El impacto de las enfermedades de especies de vida silvestre introducidas sobre la poblaciones locales llegó a ser un tema reciente de prioridad mundial, el cual es crítico cuando el riesgo de enfermedad involucra las industrias ganaderas y la salud humana $(1,8-10)$. Los antílopes negros ( $A$. cervicapra) se introdujeron a México por su importancia como trofeo de caza. La población estudiada en la unidad de cacería estaba compuesta por 60 antílopes negros adultos (8 machos y 52 
Blackbucks dead animals presented paleness and jaundice of the mucosal membrane of the oral cavity, also hydrothorax, hydropericardium and ascitis were observed. Both atrophy with gelatinous degradation of adipose tissue in coronary artery, and an injury to abomasum and edema in mucosal tissue were detected (Figure $2 b, c)$. The gross and histopathological lesions were consistent with a hemorrhagic parasitic abomasitis, catarrhal and hemorrhagic enteritis, hepatic necrosis, bilateral congestive distention of heart and fibrinonecrotic bronchopneumonia. Also, a high number of Trichostrongylids eggs were observed (Figure 2d). The examination of abdominal cavity show several parasitic structures, those were removed and identified under light microscopy as compatible with Haemonchus spp., Setaria spp. (Figure 2e), and Trichostrongylids. Consistent with other studies, the total burden of gastrointestinal nematodes was dominated by abomasal parasites characteristic for cattle and wild ruminants, i.e. Haemonchus spp. and Trichostrongylids $(4,5,11)$. Both nematodes cause lesions consistent with injuries presented at necropsy of animals examined. While Setaria spp. not cause injury in to abdominal cavity (12).

The presence of endoparasites on blackbucks was $11.67 \%$ where a prevalence of 25.6 $30 \%$ for Trichostrongylids and/or Haemonchus spp. were reported for California bighorn (Ovis canadensis califoriniana), Rocky Mountain bighorn ( $O$. canadensis canadensis), white-tailed deer (Odocoileus virginianus) and sambar deer (Cervus unicolor) $(9,11,13)$. Whereas studies and case reports of blackbucks reported prevalences of gastrointestinal nematodes ranging from 65 to $100 \%(4,5,11)$.

The hematological analysis revealed the presence of icteric animal with low values for packed cell volume and hemoglobin concentration ( $<8 \mathrm{~g} \mathrm{dL}^{-}$ ${ }^{1}$ ) on blood samples; also, Anaplasma marginale (10-15 cells per camp) was detected at light microscopy examination with Giemsa-stained thin blood smears of meningeal and splenic vessels (Figure 2f). A. marginale usually infects cattle however exist reports in wildlife ungulates kept as hunting species by Mexican ranchers infected with this pathogen agent (14-15). This hemoparasite is present in populations of whitetailed deer from the northeast of Mexico where display a reported prevalence from 20.0 to $69.7 \%$ $(7,15)$. The ectoparasites found in blackbucks dead animals were $B$. microplus and $H$. irritans. Both are consider as vectors for biological and mechanical transmission respectively $(14,15,17)$. Our knowledge this is the first journal report of the presence of Setaria spp. and A. marginale hembras reproductoras). La tasa de mortalidad general fue del $11.67 \%$, pero la tasa específica por sexo fue del $25 \%(n=2)$ y $9.62 \%(n=5)$ para machos y hembras, respectivamente.

Los antílopes negros muertos presentaban palidez e ictericia en la membrana mucosa de la cavidad oral; además se observó hidrotórax, hidropericardio y ascitis. Se detectó tanto atrofia con degradación gelatinosa de tejido adiposo en la arteria coronaria, como una lesión en el abomaso y edema en el tejido de la mucosa (Figura 2b,c). Las lesiones masivas e histopatológicas eran consistentes con una abomasitis parasitaria hemorrágica, enteritis hemorrágica y catarral, necrosis hepática, distensión congestiva bilateral del corazón y bronconeumonía fibronecrótica. También se observó un alto número de huevos de Trichostrongylidae (Figura 2d). El examen de la cavidad abdominal mostró algunas estructuras parasitarias, las cuales se removieron y se identificaron, con microscopía de luz, como compatibles con Haemonchus spp., Setaria spp. (Figura 2e), y Trichostrongylidae. De acuerdo con otros estudios, la carga total de nematodos gastrointestinales estaba dominada por parásitos abomasales característicos del ganado y rumiantes silvestres, es decir Haemonchus spp y Trichostrongylidae $(4,5,11)$. Ambos nematodos causan lesiones consistentes con las presentadas en la necropsia de los animales examinados. Mientras que Setaria spp. no causa lesiones en la cavidad abdominal (12).

La presencia de endoparásitos en los antílopes negros fue del $11.67 \%$, reportándose una prevalencia que oscila de 25.6 a $30 \%$ para Trichostrongylidae y/o Haemonchus spp. para el cimarrón californiano (Ovis canadensis califoriniana), el cimarrón de las Montañas Rocosas (O. canadensis canadensis), el venado cola blanca (Odocoileus virginianus) y el ciervo Sambar (Cervus unicolor) $(9,11,13)$. Mientras que los estudios e informes de casos de antílopes negros reportaron prevalencias de nematodos gastrointestinales que varían desde el 65 al $100 \%(4,5,11)$.

Las muestras de sangre sometidas a análisis hematológicos revelaron la presencia de animal ictérico con bajos valores en la concentración de hematocritos y hemoglobina $\left(<8 \mathrm{~g} \mathrm{dL}^{-1}\right)$. También se detectó Anaplasma marginale (10-15 células por campo) en los vasos meníngeos y esplénicos, mediante un examen con microscopía de luz en frotis delgados de sangre, preparados con la tinción de Giemsa (Figura 2f). El A. marginale usualmente infecta el ganado, sin embargo existen reportes de ungulados de vida silvestre, mantenidos como especies de caza por rancheros mexicanos, infectados con el agente patógeno (14-15). Este hemoparásito existe en poblaciones de venados 
in blackbucks ( $A$. cervicapra) from hunting unit with in free-ranging.

Based on the findings of this report, we can hypothesize that blackbucks acquired parasites at their original location at the state of Veracruz, but the relocation process associated with stress, trauma, ticks, fly-bites and malnutrition are considered to have contributed to the death of the animals. Once the diagnosis was reached, the treatment measures were implemented for controlling and eradicating of diseases, and consisted of a strict segregation of all remaining blackbucks from any other animals, application of oxytetracycline ( $1 \mathrm{~mL}$ per $10 \mathrm{~kg}$ body weight) and oral Ivermectin (22,23-dihydroavermectin $\mathrm{B} 1 \mathrm{a}+22,23$-dihydroavermectin B1b9) as treatment against internal and external parasites (biting flies and ticks). After these measures were carried out, no further fatality cases were present in blackbucks ( $A$. cervicapra) for this hunting unit.

In conclusion the present case represents the first report of the presence of Setaria spp. and $A$. marginale in blackbucks ( $A$. cervicapra) from hunting unit with in free-ranging. This findings may involve the blackbuks as reservoirs for $A$. marginale because exist the appropriated vectors for biological and mechanical transmission $(14,15,17)$ Additionally, this case indicated the importance of monitoring levels of parasitic infection in hunting units or their respective freeranging and may invite a more comprehensive study into the epidemiology, pathogenesis, treatment and prophylaxis of parasite diseases in wild mammals and their possible relation with domestic organisms.

\section{Acknowledgments}

The study was supported by Universidad Autonoma de Tamaulipas. The publication of this paper was supported by the Fondo Mixto de Fomento a la Investigación Científica y Tecnológica CONACYT - Gobierno del Estado de Tamaulipas (México). cola blanca procedentes del noreste de México, mostrando una prevalencia reportada del 20.0 al $69.7 \%(7,15)$. Los ectoparásitos encontrados en los antílopes negros muertos eran $B$. microplus y $H$. irritans. Ambos son considerados vectores para la transmisión biológica y mecánica respectivamente $(14,15,17)$. En nuestro conocimiento este es el primer informe de la actividad de Setaria spp. y $A$. marginale en antílopes negros ( $A$. cervicapra) procedentes de unidades de cacería con crianza en libertad.

Basados en las conclusiones de este informe, podemos plantear la hipótesis de que los antílopes adquieren los parásitos en sus lugares de origen, en el estado de Veracruz, y se considera que el proceso de reubicación relacionado con estrés, trauma, garrapatas, picadura de moscas y mala nutrición ha contribuido a la muerte de los animales. Una vez obtenido el diagnóstico, se implementaron medidas para el tratamiento, con el fin de controlar y erradicar las enfermedades. Estas medidas consistieron en una separación estricta de todos los antílopes negros restantes de los otros animales, aplicación de oxytetracyclina (1 $\mathrm{mL}$ por $10 \mathrm{~kg}$ de peso corporal) e Ivermectina oral (22,23-dihydroavermectina B1a + 22,23-dihydroavermectina B1b9) como tratamiento contra los parásitos internos y externos (moscas y garrapatas). En estas unidades de cacería no se presentaron más casos fatales de antílopes negros ( $A$. cervicapra), después de que se implementaran estas medidas.

En conclusión, este caso representa el primer informe de la presencia de Setaria spp. y $A$. marginale en antílopes negros ( $A$. cervicapra) procedentes de unidades de cacería con crianza en libertad. Estos resultados implican que los antílopes pueden ser depósitos de $A$. marginale, ya que existen los vectores apropiados para su transmisión biológica y mecánica $(14,15,17)$. Adicionalmente, este caso demostró la importancia de supervisar los niveles de infección parasitaria en las unidades de cacería o en sus respectivos lugares de crianza en libertad y podrían invitar a un estudio exhaustivo de la epidemiología, patogénesis, tratamiento y profilaxis de las enfermedades parasitarias en mamíferos silvestres y su posible relación con microorganismos nativos.

\section{Agradecimientos}

El estudio recibió el apoyo de la Universidad Autónoma de Tamaulipas. La publicación de este documento se realizó con el apoyo del Fondo Mixto de Fomento a la Investigación Científica y Tecnológica CONACYT - Gobierno del Estado de Tamaulipas (México). 


\section{REFERENCES}

1. Álvarez-Romero JG, Medellín RA, Oliveras de Ita A, Gómez de Silva H, Sánchez O. Animales exóticos en México: una amenaza para la biodiversidad. Secretaría de Medio Ambiente y Recursos Naturales; 2008.

2. Álvarez-Romero J, Medellín RA. Antilope cervicapra. Vertebrados superiores exóticos en México: diversidad, distribución y efectos potenciales. Distrito Federal (Mex). Sistema Nacional de Información sobre BiodiversidadComisión Nacional para el Conocimiento y Uso de la Biodiversidad (SNIB-CONABIO). 2005 pp 1-16. Proyecto U020.

3. Universidad Nacional Autónoma de México. Bases de datos SNIB-CONABIO. Proyecto U020. México. D.F.

4. Isvaran K. Female grouping best predicts lekking in blackbuck (Antilope cervicapra). Behav Ecol Sociobiol 2005; 57(3):283-294

5. Fagiolini $M$, Lia RP, Laricchiuta $P$, Cavicchio $P$, Mannella R, Cafarchia C, Otranto D, Finotello R, Perrucci S. Gastrointestinal parasites in mammals of two Italian zoological gardens. J Zoo Wildlife Med 2010; 41(4):662-670.

6. Goossens E, Dorny P, Boomker J, Vercammen $F$, Vercruysse J. A 12-month survey of the gastro-intestinal helminths of antelopes, gazelles and giraffids kept at two zoos in Belgium. Vet Parasitol 2005; 127(3-4):303312.

7. Sedlák K, Bártová E. Seroprevalences of antibodies to Neospora caninum and Toxoplasma gondii in zoo animals. Vet Parasitol 2006; 136(3-4):223-231

8. Krausman PR, Bleich VC. Conservation and management of ungulates in North America. Int J Environ Stud 2013; 70(3):372-382

9. Yaralioúlu S, Sahin T, Sindak N, Yurekli UF. Investigation of some hematologic and biochemical parameters in the serum of gazelles (Gazella subgutturosa) in Ceylanpinar, Sanliurfa, Turkey. Turk J Vet Anim Sci 2004; 28(2):369-372
10. Guirisa ADM, Rojasc HNM, Berovidesc AV, Sosab PJ, Pereza EME, Cruzd AE, Chavezd HC, Mogueld AJA, Jimenez-Coelloe M, OrtegaPachecof A. Biodiversity and distribution of helminths and protozoa in naturally infected horses from the biosphere reserve "La Sierra Madre de Chiapas", Mexico. Vet Parasitol 2010; 170(3-4):268-277

11. Vázquez-Prats VM, Flores-Crespo J, Santiago-Valencia C, Herrera-Rodríguez D, Palacios-Franquez A, Liébano-Hernández $E$, Pelcastre-Ortega A. Frecuencia de nematodos gastroentéricos en bovinos de tres áreas de clima subtropical húmedo de México. Tec Pecua Mex 2004; 42(2):237-245

12. Quiroz R.H. Parasitología y enfermedades parasitarias de animales domésticos. Ed. Limusa. México DF. 2005.

13. Contreras J, Mellink E, Martínez R, Medina G. Parásitos y enfermedades del venado bura (Odocoileus hemionus fuliginatus) en la parte norte de la Sierra San Pedro Mártir, Baja California, México. Rev Mex Mastozoo 2007; 11(1):8-20.

14. Fuente J, Ruybal P, Mtshali MS, Naranjo V, Shuqing $\mathrm{L}$, Mangold $\mathrm{AJ}$, Rodríguez SD, Jiménez R, Vicente J, Moretta R, Torina A, Almazán C, Mbati PM, Echaide ST, Farber M, Rosario-Cruz R, Gortazar C, Kocan KM. Analysis of world strains of Anaplasma marginale using major surface protein $1 \mathrm{a}$ repeat sequences. Vet Microbiol 2005; 119(2-4):382-390

15. Rodríguez SD, García MA, Jiménez $R$, Vega C Molecular epidemiology of bovine anaplasmosis with a particular focus in Mexico. Infect Genet Evol 2009; 9(6):1092-1101.

16. Ditchkoff SS, Hoofer SR, Lochmiller RL, Masters RE, Van Den Bussche RA. MHCDRB evolution provides insight into parasite resistance in white-tailed deer. Southwest Nat 2005;50(1):57-64.

17. Torres L, Almazán C, Ayllón N, Galindo RC, Rosario-Cruz R, Quiroz-Romero H, Gortazar C, de la Fuente J. Identification of microorganisms in partially fed female horn flies, Haematobia irritans. Parasitol Res 2012; 111(3):1391-1395. 